\title{
Availability of lysine in protein concentrates as determined by the slope-ratio assay with chicks and comparisons with rat, pig and chemical assays
}

\author{
BY E. J. MAJOR \\ NSW Departmenl of Agriculture, Poultry Research Station, Seven Hills, \\ New South Wales 2147, Australia \\ AND E. S. BATTERHAM \\ NSW Department of Agriculture, Agricultural Research Centre, Wollongbar, \\ New South Wales 2480, Australia
}

(Received 18 December 1980 - Accepted 25 June 1981)

1. A slope-ratio assay was developed to determine the availability of lysine in protein concentrates for chicks. Two protein concentrates were assessed per assay, using three levels of incorporation into the basal diet.

2. Availability of lysine, expressed as a proportion of total lysine in five protein concentrates was: cottonseed meal 0.83 , fish meal 1.00 , meat-and-bone meal 0.86 , soya-bean meal 0.93 , sunflower meal 1.01 .

3. The five protein concentrates had previously been assayed for available lysine with slope-ratio assays for pigs and rats (Batterham et al. 1979; Batterham et al. 1981). There was little relationship between the results for chicks and those for pigs and rats. For pigs, availability estimates ranged from 0.43 for cottonseed meal to 0.89 for fish meal. For rats, availability estimates ranged from 0.49 for sunflower meal to 1.04 for fish meal.

4. The results for chicks were in closer agreement with values obtained using the Silcock available-lysine assay (Roach et al. 1967) and the direct I-fluoro-2,4-dinitrobenzene procedure (Carpenter, 1960). By contrast, there was little relationship between the chemical tests and results for pigs or rats.

Batterham et al. (1979) reported that the availabilty for pigs of lysine in protein concentrates, as assessed by the slope-ratio assay, ranged from 0.43 in cottonseed meal to 0.89 in fish meal. These differences were also detected by slope-ratio assays with rats, but not by the chemical Silocl: available-lysine assay (Roach et al. 1967), nor by the direct 1-fluoro-2,4-dinitrobenzent: (FDNB) procedure (Carpenter, 1960).

This paper reports the development of a slope-ratio assay for lysine with chicks. Samples of protein concentrate that had previously been assayed for lysine using slope-ratios assays with pigs and rats (Batterham et al. 1979; Batterham et al. 1981) were used in the chick assays to allow a direct comparison to be made of the ability of chicks, pigs and rats to utilize lysine from different protein sources. The relationship between the Silcock availablelysine test (Roach et al. 1967) and the direct FDNB procedure (Carpenter, 1960) and chick response was also examined to determine if these two techniques were suitable for estimating lysine availability in the different protein sources for chicks.

\section{EXPERIMENTAL \\ Chick slope-ratio assay}

Diets. Two protein concentrates were assayed in each experiment. Ten diets were used; the basal diet (blanks), three diets to determine the chick's response to standard lysine, and six for the two protein concentrates (three diets per protein concentrate). The basal diet (Table 1) was formulated using a hiछ,h-proten wheat (Timgalen cultivar) which in combination with wheat gluten, produced a ysine deficient $(4.9 \mathrm{~g} / \mathrm{kg})$ diet (Table 2). Methionine, arginine 
Table 1. Composition $(\mathrm{g} / \mathrm{kg})$ of the basal diet used for the slope-ratio assay with chicks

\begin{tabular}{lc}
\hline \hline Wheat & 640 \\
Wheat gluten & 110 \\
Sunflower oil & $27 \cdot 5$ \\
Mineral and vitamin premix & $3 \cdot 5$ \\
Tricalcium phosphate & 30 \\
Salt & $2 \cdot 5$ \\
DL-methionine & $1 \cdot 5$ \\
Glycine & $2 \cdot 3$ \\
& $1 \cdot 9$ \\
& $180 \cdot 8$ \\
\hline
\end{tabular}

* Contributed the following (/kg diet): manganese dioxide $80 \mathrm{mg}$, zine oxide $50 \mathrm{mg}$, sodium molybdate $0.5 \mathrm{mg}$, cupric oxide $6 \mathrm{mg}$, iodine $0.8 \mathrm{mg}$, retinol equivalent $3 \mathrm{mg}$, cholecalciferol $45 \mu \mathrm{g}, \alpha$-tocopherol equivalent $2.5 \mathrm{mg}$, menadione-sodium bisulphite $1.2 \mathrm{mg}$, riboflavin $4 \mathrm{mg}$, pantothenic acid $5.5 \mathrm{mg}$, pyridoxine $4 \mathrm{mg}$, pteroylmonoglutamic acid $1 \mathrm{mg}$, nicotinic acid $20 \mathrm{mg}$, biotin $50 \mu \mathrm{g}$, cyanocobalamin $7.5 \mu \mathrm{g}$, choline chloride $100 \mathrm{mg}$, ethoxyquin $125 \mathrm{mg}$.

Table 2. Composition $(\mathrm{g} / \mathrm{kg})$ of the wheat, wheat gluten and basal diet used for the growth assay with chicks

\begin{tabular}{|c|c|c|c|}
\hline & Wheat & $\begin{array}{l}\text { Wheat } \\
\text { gluten }\end{array}$ & $\begin{array}{c}\text { Basal } \\
\text { diet }\end{array}$ \\
\hline Crude protein (nitrogen $\times 6 \cdot 25$ ) & 192 & 826 & 219 \\
\hline Dry matter & 890 & 927 & 896 \\
\hline Petroleum-ether extract & 21 & 8 & 42 \\
\hline Crude fibre & 31 & 1 & 20 \\
\hline \multicolumn{4}{|l|}{ Essential amino acids } \\
\hline Threonine & $5-4$ & 21 & $5 \cdot 8$ \\
\hline Glycine & $7 \cdot 1$ & 26 & 9.7 \\
\hline Valine & $7 \cdot 7$ & 32 & $8 \cdot 4$ \\
\hline Methionine + cystine & $4 \cdot 6$ & 28 & $7 \cdot 5$ \\
\hline Isoleucine & $5 \cdot 8$ & 32 & $7 \cdot 2$ \\
\hline Leucine & $12 \cdot 3$ & 60 & $14 \cdot 5$ \\
\hline Phenylalanine + tyrosine & $15 \cdot 5$ & 69 & $17 \cdot 5$ \\
\hline Histidine & $4 \cdot 0$ & 17 & $4 \cdot 4$ \\
\hline Lysine & $5 \cdot 2$ & 14 & 4.9 \\
\hline Arginine & $8 \cdot 4$ & $-{ }^{*}$ & 9.9 \\
\hline
\end{tabular}

* Not adequately resolved, estimated at $29 \mathrm{~g} / \mathrm{kg}$.

and glycine were added to ensure near adequacy according to the estimates of the National Research Council (1971). In each experiment three levels of lysine were used to determine the chicks's response to standard lysine, which was obtained by the addition to the basal diet of L-lysine monohydrochloride (anhydrous, $98 \%$ pure; Ajinomoto Co. Inc., Japan). The protein concentrates were incorporated into the basal diets to provide the same three levels of total lysine at the expense of wheat starch. The actual levels of total lysine used in each experiment varied according to the concentration of lysine in the test proteins and limitations imposed by other nutrients (crude fibre in cottonseed and sunflower meal, calcium in meat-and-bone meal). The level of tricalcium phosphate was reduced to make allowance for the calcium and phosphorus in the diets containing meat-and-bone meal. Dietary energy was maintained at $13.33 \mathrm{MJ}$ metabolizable energy $/ \mathrm{kg}$ diet using wheat starch and sunflower oil as non-protein energy sources.

The chemical compositions of the cottonseed, fish, meat-and-bone and soya-bean meals 
were given by Batterham et al. (1979) and that of the sunflower meal by Batterham $e t$ al. (1981) (sunflower meal no. 3). The cottonseed, sunflower and soya-bean meals were 'prepress' solvent-extracted and the fish and the meat-and-bone meals were dry rendered. All meals were locally produced, except fish meal which was imported from South Africa. The cottonseed meal contained 8300 and $260 \mathrm{mg}$ total and free gossypol $/ \mathrm{kg}$ respectively and ferrous sulphate was added in an attempt to inactivate any possible effects.

Animals and procedure. The ten diets were arranged in a randomized design with four cages of chicks allocated to each diet. Each cage contained equal numbers of 8-d-old female commercial 'Hyline' broiler chicks selected for uniformity of weight after a $5 \mathrm{~h}$ fast. The number of chicks housed ir. each cage varied from seven to nine per experiment. The cages, which contained electrical brooder elements, were located in a controlled environment room maintained at $23 \pm 2^{\circ}$ and $65 \pm 5 \%$ relative humidity. Fluorescent lighting was supplied between 01.00 and 24.00 hours daily. Each cage had an individual food trough and shared a water trough with one adjacent cage. Diets, which were available at all times, were allocated at random to cages of chicks. On the morning of the ninth day on experimental diets, the chicks and remaining food were weighed. The chicks were then returned to their cages for a $7 \mathrm{~h}$ fast during which time they had access to water. They were then weighed and the experiment terminated. Chick response was assessed in terms of weight gain/d, food conversion efficiency ( $\mathrm{g}$ weight gain/g food intake; FCE), fasted weight gain/d, and fasted FCE ( $\mathrm{g}$ fasted weight gain/g food intake). The results for weight gain/d, FCE, fasted weight gain/d and fasted FCE were analysed by the slope-ratio technique of Finney (1964) for multiple assays. The availabilities and their standard deviations were calculated. Two separate assays were conducted for the cottonseed meal, fish meal, meat-and-bone meal and soya-bean meal to give an indication of the reproducibility of the assay.

\section{RESULTS}

Performace results for the chicks are presented in Tables 3 and 4 . The availability of lysine in the five protein concentrates, as determined by the four production criteria, is presented in Table 5. Availability estimates based on weight gain/d and FCE varied slightly but there was no consistent pattern. There was also little or no effect of fasting the chicks on availability estimates. All proteins had high lysine availabilities for chicks. There was generally good agreement between replicates of availability estimates betwen experiments except for fish meal, where values varied from 1.09 to 0.91 for fasted FCE and soya-bean meal, where values varied between 0.81 to 1.01 for weight gain $/ \mathrm{d}$.

The availability of lysine in the five protein concentrates for chicks is compared to chemical estimates and estimates for pigs and rats in Table 6. This comparison indicates that the availability of lysine in the cottonseed meal, meat-and-bone meal and sunflower meal was much higher for chicks than for pigs and rats. There was also closer agreement between the results for chicks and the chemical available-lysine estimates. By contrast, there was little agreement between the chemical values and those for the pig or rat.

\section{DISCUSSION}

The slope-ratio assays were conducted within the linear portion of the chick's response to lysine, and all assays were statistically valid. Agreement of replicate values of the assays (Carpenter et al. 1972). The potency estimates for assay no. 1 with fish meal and for the sunflower meal were slightly higher than 1.0 and this discrepancy may have been related to errors associated with the low inclusion levels of total lysine for these meals $(0.51-1.54 \mathrm{~g}$ lysine $/ \mathrm{kg}$ ). These two me:als were assayed in the one experiment to enable a direct 
Table 3. Weight gain $(\mathrm{g} / \mathrm{d})$ and food conversion efficiency ( $\mathrm{g}$ weight gain/g food intake; $F C E$ ) on a full-fed and fasted basis* of chicks fed on the diets for the slope-ratio assays for lysine in cottonseed meal and fish meal

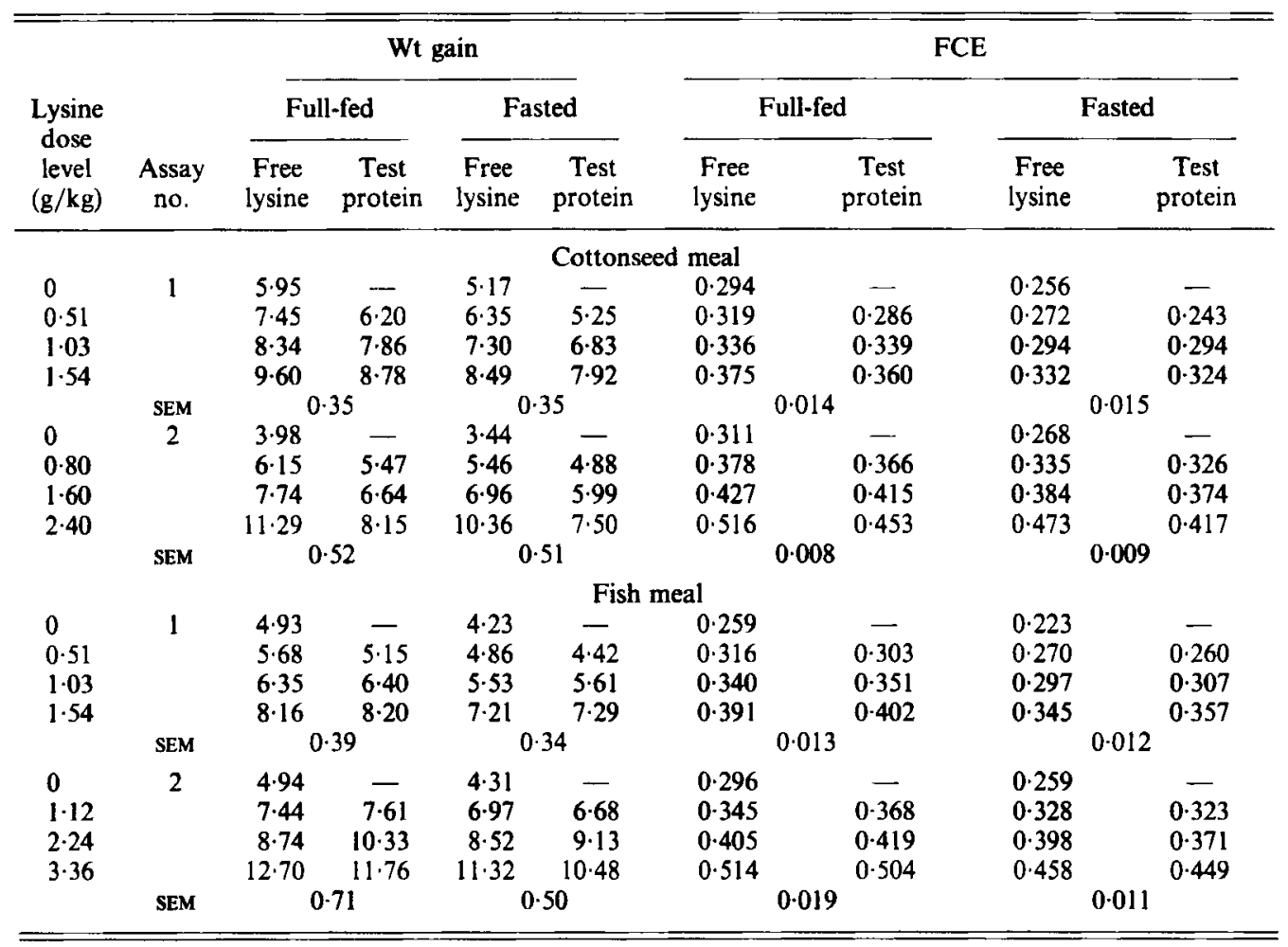

* The chicks were weighed 'immediately off food' and after a $7 \mathrm{~h}$ fast.

comparison to be made with chicks of two meals that had showed large differences in lysine availability for pigs and rats. The high fibre and low metabolizable energy content of the sunflower meal restricted the inclusion level of that meal. As the fish meal was compared at similar lysine levels, its inclusion level was also low. When a higher inclusion level of lysine $(1 \cdot 12-3.36 \mathrm{~g} / \mathrm{kg})$ was used in assay no. 2 for fish meal, lower potency estimates resulted, on a fasted basis.

In our assays, the dietary crude protein content varied as a result of differences in the concentration of lysine in the protein concentrates. In the development of other assays (e.g. Uwaegbute \& Lewis, $1966 a$; Njike et al. 1975) the amino acid concentration of all diets was kept constant. This was done to avoid the 'protein effect' which is a possible depression of the availability estimate due to the addition of imbalanced test protein to the diets. However, they tested the effects of addition of imbalanced protein to their basal diets at near maximal test amino acid dose level, where the addition of imbalanced protein is more likely to have effects. In our assay, the dose responses were selected to be linear and the top levels were less than $70 \%$ of the estimated requirement of lysine by chicks (National Research Council, 1971). The effect of variation in dietary protein concentration was discussed by Batterham et al. (1979) who concluded that provided food intake was taken into account, availability estimates were unlikely to be affected. Similarly, Fisher et al. (1960) found that whilst imbalances reduced food consumption there was no evidence that the efficiency of utilization of the limiting amino acid was affected. In addition, Robel \& Frobish 
Table 4. Weight gain $(\mathrm{g} / \mathrm{d})$ and food conversion efficiency ( $\mathrm{g}$ weight gain $/ \mathrm{g}$ food intake; FCE) on a full-fed and fasted basis* of chicks fed the diets for the slope-ratio assays for lysine in meat-and-bone meal, soya-bean meal and sunflower meal

\begin{tabular}{|c|c|c|c|c|c|c|c|c|c|}
\hline \multirow{3}{*}{$\begin{array}{c}\text { Lysine } \\
\text { dose } \\
\text { level } \\
(\mathrm{g} / \mathrm{kg})\end{array}$} & \multirow[b]{3}{*}{$\begin{array}{c}\text { Assay } \\
\text { no. }\end{array}$} & \multicolumn{4}{|c|}{ Wt gain } & \multicolumn{4}{|c|}{ FCE } \\
\hline & & \multicolumn{2}{|c|}{ Full-fed } & \multicolumn{2}{|c|}{ Fasted } & \multicolumn{2}{|c|}{ Full-fed } & \multicolumn{2}{|c|}{ Fasted } \\
\hline & & $\begin{array}{c}\text { Free } \\
\text { lysine }\end{array}$ & $\begin{array}{c}\text { Test } \\
\text { protein }\end{array}$ & $\begin{array}{c}\text { Free } \\
\text { lysine }\end{array}$ & $\begin{array}{c}\text { Test } \\
\text { protein }\end{array}$ & $\begin{array}{c}\text { Free } \\
\text { lysine }\end{array}$ & $\begin{array}{c}\text { Test } \\
\text { protein }\end{array}$ & $\begin{array}{c}\text { Free } \\
\text { lysine }\end{array}$ & $\begin{array}{c}\text { Test } \\
\text { protein }\end{array}$ \\
\hline \multicolumn{10}{|c|}{ Meat-and-bone meal } \\
\hline $\mathbf{0}$ & 1 & 5.66 & - & - & - & $0 \cdot 276$ & - & - & - \\
\hline 0.93 & & 7.80 & $8 \cdot 17$ & - & - & 0.362 & 0.334 & - & - \\
\hline 1.86 & & 10.70 & $10 \cdot 67$ & - & - & 0.399 & 0.369 & - & - \\
\hline 2.79 & & $12 \cdot 47$ & 11.68 & - & - & 0.450 & 0.454 & - & - \\
\hline & SEM & \multicolumn{2}{|c|}{0.45} & \multirow{2}{*}{\multicolumn{4}{|c|}{0.014}} & & \\
\hline 0 & 2 & 3.86 & - & $3 \cdot 15$ & & & & 0.238 & - \\
\hline 0.94 & & $5 \cdot 48$ & 5.68 & $4 \cdot 68$ & 4.95 & $0 \cdot 347$ & 0.357 & 0.296 & 0.311 \\
\hline 1.87 & & $7 \cdot 15$ & 6.86 & $6 \cdot 16$ & 6.02 & 0.404 & 0.384 & 0.347 & 0.337 \\
\hline \multirow[t]{3}{*}{2.81} & & $9 \cdot 53$ & $8 \cdot 37$ & 8.41 & $7 \cdot 29$ & 0.469 & 0.433 & 0.414 & 0.377 \\
\hline & SEM & \multicolumn{2}{|c|}{0.43} & \multicolumn{2}{|c|}{0.41} & \multicolumn{2}{|c|}{0.013} & \multicolumn{2}{|c|}{0.014} \\
\hline & \multicolumn{9}{|c|}{ Soya-bean meal } \\
\hline 0 & 1 & 3.86 & -.. & $3 \cdot 15$ & - & 0.291 & - & 0.238 & - \\
\hline 0.94 & & 5.48 & 5.44 & 4.68 & 4.62 & 0.347 & 0.339 & 0.296 & 0.288 \\
\hline 1.87 & & $7 \cdot 15$ & $7 \cdot 22$ & $6 \cdot 16$ & $6 \cdot 30$ & 0.404 & $0 \cdot 388$ & 0.347 & 0.338 \\
\hline \multirow[t]{2}{*}{$2 \cdot 81$} & & $9 \cdot 53$ & $9 \cdot \llbracket 6$ & 8.41 & 8.44 & 0.469 & 0.455 & 0.414 & 0.401 \\
\hline & SEM & \multicolumn{2}{|c|}{0.43} & \multicolumn{2}{|c|}{0.41} & \multicolumn{2}{|c|}{0.013} & \multicolumn{2}{|c|}{0.014} \\
\hline 0 & 2 & 3.98 & & 3.44 & - & 0.311 & - & 0.268 & - \\
\hline 0.80 & & 6.15 & 5.49 & 5.46 & 4.89 & $0 \cdot 378$ & $0 \cdot 367$ & 0.335 & 0.326 \\
\hline 1.60 & & 7.74 & $7 \cdot 56$ & 6.96 & 6.90 & 0.427 & 0.433 & 0.384 & 0.395 \\
\hline \multirow[t]{3}{*}{$2 \cdot 40$} & & 11.29 & $9 . \subseteq 8$ & $10 \cdot 36$ & 8.76 & 0.516 & 0.489 & 0.473 & 0.447 \\
\hline & SEM & \multicolumn{2}{|c|}{0.52} & \multicolumn{2}{|c|}{0.51} & \multicolumn{2}{|c|}{0.008} & \multicolumn{2}{|c|}{0.009} \\
\hline & \multicolumn{9}{|c|}{ Sunflower meal } \\
\hline 0 & 1 & 4.93 & - & & & 0.259 & - & & - \\
\hline 0.51 & & 5.68 & 5.43 & 4.86 & 4.67 & 0.316 & 0.328 & 0.270 & 0.282 \\
\hline & & 6.35 & 6.46 & 5.53 & 5.78 & 0.340 & 0.348 & 0.297 & 0.312 \\
\hline \multirow{2}{*}{1.54} & & $8 \cdot 16$ & $7 \cdot 40$ & $7 \cdot 21$ & 6.52 & 0.391 & 0.379 & 0.345 & 0.334 \\
\hline & SEM & & 39 & & 34 & & & & \\
\hline
\end{tabular}

* The chicks were weighed 'immediately off food' and after a $7 \mathrm{~h}$ fast.

(1977) found that excess amino acids simulating that contributed by soya-bean meal had no effect on the availability estimate for sulphur amino acids in soya-bean meal. With our results, all availability estimates were high, again indicating lack of any substantial depression of lysine availability due to variation in dietary crude protein content.

It is difficult to compare our availability estimates with results of other workers as there is a dearth of information on lysine availability in commercially prepared protein concentrates for chicks. This situation is made more difficult in that many of the earlier published results do not ircude a proximate analysis and total amino acid profile which are needed in order to characterize meals. The result of 0.93 for soya-bean meal is similar to estimates of 0.90 by Robel \& Frobish (1977) and 0.97 (Guo et al. 1971). For fish meal, our value of 0.94 agrees with that of 0.90 (Guo et al. 1971) but is slightly higher than that of 0.77 by Uwaegbute \& Lewis $(1966 b)$. For meat-and-bone meal, our result of 0.86 is considerably higher than those of Guo et al. (1971) (0.52), and Uwaegbute \& Lewis (1966b) $(0.53)$. However, our value is similar to that for other local meat-and-bone meals that we have tested for chicks (unpublished results). 
Table 5. Availability of lysine (proportion of total) in the protein concentrates as assessed with chicks using weight gain/d, food conversion efficiency ( $g$ weight gain/g food intake), fasted weight gain/d, and fasted food conversion efficiency as the criteria for availability

(Mean values and standard deviations)

\begin{tabular}{|c|c|c|c|c|c|c|c|c|c|}
\hline \multirow{2}{*}{$\begin{array}{l}\text { Protein } \\
\text { concentrate }\end{array}$} & \multirow{2}{*}{$\begin{array}{c}\text { Assay } \\
\text { no. }\end{array}$} & \multicolumn{2}{|c|}{$\mathrm{Wt}$ gain $/ \mathrm{d}$} & \multicolumn{2}{|c|}{$\begin{array}{c}\text { Food } \\
\text { conversion } \\
\text { efficiency }\end{array}$} & \multicolumn{2}{|c|}{$\begin{array}{c}\text { Fasted } \\
\text { wt gain } / \mathrm{d}\end{array}$} & \multicolumn{2}{|c|}{$\begin{array}{l}\text { Fasted food } \\
\text { conversion } \\
\text { efficiency }\end{array}$} \\
\hline & & Mean & SD & Mean & SD & Mean & SD & Mean & SD \\
\hline \multirow[t]{2}{*}{ Cottonseed meal } & 1 & 0.74 & 0.09 & 0.83 & 0.19 & $0 \cdot 78$ & $0 \cdot 10$ & 0.87 & $0 \cdot 20$ \\
\hline & 2 & 0.63 & 0.08 & $0 \cdot 75$ & 0.04 & 0.64 & 0.08 & 0.78 & 0.05 \\
\hline \multirow[t]{2}{*}{ Fish meal } & 1 & 0.98 & $0 \cdot 13$ & 1.08 & $0 \cdot 14$ & 1.00 & $0 \cdot 13$ & 1.09 & $0 \cdot 13$ \\
\hline & 2 & $1 \cdot 02$ & $0 \cdot 11$ & 1.02 & 0.11 & 0.95 & 0.08 & 0.91 & 0.06 \\
\hline \multirow[t]{2}{*}{ Meat-and-bone meal } & 1 & 0.91 & 0.07 & 0.92 & 0.09 & - $^{*}$ & - & - & - \\
\hline & 2 & 0.86 & 0.08 & 0.84 & 0.08 & 0.87 & 0.09 & 0.86 & 0.09 \\
\hline \multirow[t]{2}{*}{ Soya-bean meal } & 1 & $1 \cdot 01$ & 0.09 & 0.90 & 0.09 & $1 \cdot 02$ & 0.09 & 0.92 & 0.09 \\
\hline & 2 & 0.81 & 0.08 & 0.91 & $0-05$ & 0.82 & 0.08 & 0.93 & 0.05 \\
\hline Sunflower meal & 1 & 0.86 & $0 \cdot 12$ & 0.99 & 0.13 & 0.88 & $0 \cdot 12$ & $1 \cdot 01$ & 0.13 \\
\hline
\end{tabular}

- Not assessed on a fasted basis.

Table 6. Availability of lysine (proportion of total) in the protein concentrates as assessed by the chemical Silcock technique, the direct 1-fluoro-2,4-dinitrobenzene (FDNB) assay and by the slope-ratio assay with chicks, pigs and rats using food conversion efficiency as the criterion of response*

\begin{tabular}{|c|c|c|c|c|c|c|c|c|}
\hline \multirow{3}{*}{$\begin{array}{l}\text { Protein } \\
\text { concentrate }\end{array}$} & \multirow{3}{*}{$\begin{array}{c}\text { Silcock } \\
\text { assay }\end{array}$} & \multirow{3}{*}{$\begin{array}{c}\text { Direct } \\
\text { FDNB } \\
\text { assay }\end{array}$} & & & \multirow{2}{*}{\multicolumn{2}{|c|}{$\frac{\text { Slope-ratio assay } \dagger}{\text { Pigs }}$}} & \multirow{2}{*}{\multicolumn{2}{|c|}{ Rats }} \\
\hline & & & \multicolumn{2}{|c|}{ Chicks } & & & & \\
\hline & & & Mean & SD & Mean & SD & Mean & SD \\
\hline Cottonseed meal & 0.93 & 0.65 & 0.79 & 0.06 & 0.43 & 0.09 & 0.58 & $0 \cdot 11$ \\
\hline Fish meal & 0.89 & 0.90 & 0.94 & 0.08 & 0.89 & $0 \cdot 10$ & $1 \cdot 04$ & 0.26 \\
\hline Meat-and-bone meal & 0.84 & 0.79 & 0.86 & 0.09 & 0.49 & 0.09 & 0.64 & $0 \cdot 20$ \\
\hline Soya-bean meal & 0.93 & 0.77 & 0.93 & 0.07 & 0.84 & $0 \cdot 10$ & 0.89 & 0.09 \\
\hline Sunflower meal & 0.94 & 0.88 & $1 \cdot 01$ & $0 \cdot 13$ & 0.54 & $0 \cdot 10$ & 0.49 & 0.08 \\
\hline
\end{tabular}

- The results for cottonseed meal, fish meal, meat-and-bone meal and soya-bean meal are from Batterham et al. (1979) and the results for sunflower meal from Batterham et al. (1981).

$\dagger$ Fasted basis for chicks, carcass basis for pigs, and live-weight basis for rats.

There was little consistent effect of fasting the chicks at the completion of the assay on potency estimates. This may reflect the relatively fast transit time of digesta through chicks and the small capacity of the large intestines (Zebrowska, 1978). With pigs, the rate of passage of digesta is slower (Castle $\&$ Castle, 1956), the large intestines have a greater retention capacity and there are considerable differences in availability estimates based on live-weight and carcass gain (Batterham et al. 1979). With rats, the availability estimates presented in Table 6 are based on FCE on a live-weight basis; values based on carcass results may be up to 0.12 availability units lower, especially in sunflower and cottonseed meals (Batterham et al. 1981 and unpublished results). Such differences indicate a greater retention time of digesta in rats compared to chicks. 
The slope-ratio estimates of lysine availability (Table 6) indicates that the chick is more efficient in utilizing lysine from certain sources than are the pig and the rat. This could be due to the chick having a more efficient digestion and absorption system or it may be capable of utilizing forms of lysine that the pig and rat cannot. However, comparative studies of apparent amino acid digestion by chicks, pigs and rats have indicated that the pig is slightly more efficient than the chick, and the rat slightly less (Slump et al. 1977). Their study was conducted with three diets that differed considerably in over-all amino acid digestibility, although the differences appeared largely as a result of the inclusion of fibrous material in the diet and not necessarily from heat-damaged protein concentrate. Regarding forms of lysine, there is some evidence that derivatives of lysine may vary in nutritional value between species. For example, $\epsilon-N$-propionyl-L-lysine has been shown to have no nutritional value for rats (Bjarnason \& Carpenter, 1969) but can be utilized by chicks (Varnish \& Carpenter, 1975). Whatever the mechanisms responsible, the high Silcock available-lysine values in the five protein concentrates indicate that the reactions are ones not involving the $\epsilon$-amino group of lysine. Further research is needed to define the causes of the species differences in lysine availability in these meals and to determine whether it occurs in other protein concentrates.

There was general agreement between the chemical available-lysine estimates in the protein concentrates and the slope-ratio assay results for chicks but the measured range in availability was narrow for both methods. Further research is needed, over a wider range of availabilities, and with additional protein sources, before firm conclusions can be made regarding the ability of the chemical assays to predict the availability of lysine in foods for chicks.

This work was supported by financial grants from the Australian Chicken Meat Research Committee.

\section{REFEREN CES}

Batterham, E. S., Murison, R. LI. \& Lewis, C. E. (1979). Br. J. Nutr. 41, 383.

Batterham, E. S., Murison, R. Il. \& Lowe, R. F. (1981). Br. J. Nutr. 45, 401.

Bjarnason, J. \& Carpenter, K. J (1969). Br. J. Nutr. 23, 859.

Carpenter, K. J. (1960). Biochent. J. 77, 604.

Carpenter, K. J., McDonald, I. \& Miller, W. S. (1972). Br. J. Nutr. 27, 7.

Castle, E. J. \& Castle, M. E. (1956). J. agric. Sci., Camb. 47, 196.

Finney, D. J. (1964). Statistical Method in Biological Assay, 2nd ed. London: Griffin.

Fisher, H., Griminger, P., Leveille, G. A. \& Shapiro, R. (1960). J. Nutr. 71, 213.

Guo, L. S., Summers, J. D. \& Moran, E. J. Jr. (1971). Can. J. Anim. Sci. 51, 161.

National Research Council (1971). Nutrient Requirements of Poultry, 6th ed. Washington, DC: National Academy of Sciences.

Njike, M. C., Mba, A. U. \& Oyenuga, V. A. (1975). J. Sci. Fd Agric. 26, 175.

Roach, A. G., Sanderson, P. \& Williams, D. R. (1967). J. Sci. Fd Agric. 18, 274.

Robel, E. J. \& Frobish, L. T. (1777). Poult. Sci. 56, 1399

Slump, P., van Beek, L., Janssen, W. M. M. A., Terpstra, K., Lenis, N. P. \& Smits, B. (1977). In Proceedings of the Second International Symposium on Protein Metabolism and Nutrition, p. 70 [S. Tamminga, editor]. Wageningen: Centre for Agricultural Publishir.g and Documentation.

Uwaegbute, H. O. \& Lewis, D. 1966a). Br. Poult. Sci. 7, 249.

Uwaegbute, H. O. \& Lewis, D. 1966 b). Br. Poult. Sci. 7, 261.

Varnish, S. A. \& Carpenter, K. J. (1975), Br. J. Nutr. 34, 325.

Zebrowska, T. (1978). Feedstuffi, no. 53, p. 15. 